\title{
Palliative chest wall radiotherapy for a fungating and bleeding metastatic breast cancer: quality of life beyond cure
}

\author{
Deep Chakrabarti (D) , Mranalini Verma (D) , Divya Kukreja (D) , Mansi Shukla, \\ Madan Lal Brahma Bhatt
}

Department of Radiation Oncology, King George's Medical University, Lucknow, Uttar Pradesh, India

\section{Correspondence to} Dr Deep Chakrabarti; deepchakrabarti.19@gmail.com Dr Mranalini Verma; drmrinalini79@gmail.com

DC and MV contributed equally.

DC and MV are joint first authors.

Accepted 20 July 2021

\section{DESCRIPTION}

Palliative care is an integral component of comprehensive cancer care that offers reasonable symptom control and a decent quality of life beyond the chance for cure. ${ }^{1}$ A 50-year-old postmenopausal woman was seen in the oncology clinic with a progressive lump in the right breast and ulceration over the right chest wall and axilla for oneyear with associated pain and bleeding. She had no comorbidities and a WHO performance score of 1 . A $3 \times 2 \mathrm{~cm}$ non-tender lump was palpable over the right breast in the upper outer quadrant with nipple retraction, fixed to the breast tissue but not to the chest wall. A small satellite nodule was present at 10 o'clock. An approximately $8 \times 6 \mathrm{~cm}$ area of ulceration with bleeding points and everted edges was present just above the lump from the midclavicular line to the anterior axillary fold, which extended into the axillary tail (figure 1). The ipsilateral supraclavicular (SCF) lymph node was palpable.

A core biopsy from the lump revealed an infiltrating ductal carcinoma $(\mathrm{ER}+/ \mathrm{PR}+/ \mathrm{Her} 2 \mathrm{neu}-/ \mathrm{Ki} 67$ $30 \%$ ), and a fine-needle aspiration from the SCF lump showed metastatic carcinoma. Additional workup revealed metastatic lesions in bilateral lung and liver and increased uptake in multiple ribs. She was diagnosed as a case of metastatic breast cancer (MBC) (UICC TNM cT4bN3cM1).

She received palliative radiotherapy to the chest wall by a single anterior field using a telecobalt receiving a dose of 20 Gray in five fractions over one week, the prescription point being at the depth of maximum dose $\left(\mathrm{D}_{\max }\right)$ with $0.5 \mathrm{~cm}$ wet cotton bolus (figure 2). She was also started on zoledronic acid and oral letrozole, and further planned for

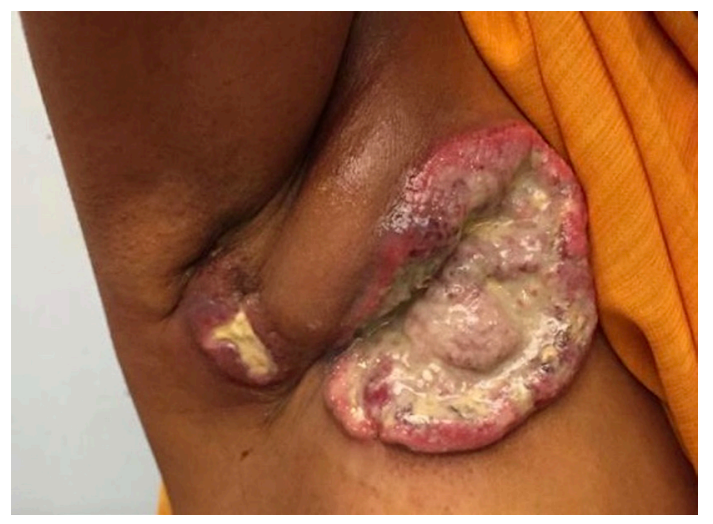

Figure 1 Ulceration in the anterior chest wall and axilla at the baseline.

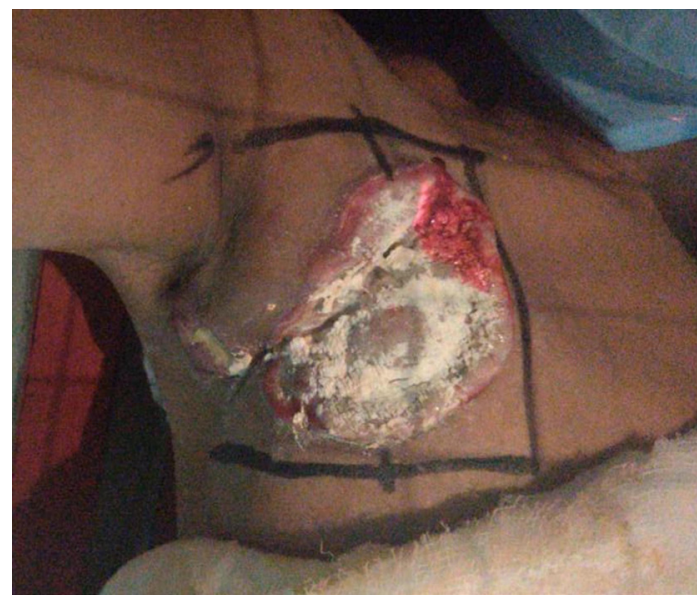

Figure 2 Radiotherapy field.

CDK4/6 inhibitor therapy. At sixweeks after radiotherapy, she had a good subjective and objective response, with relief in pain and bleeding and a reduction in the size of the ulcer with overlying crusting (figure 3). At threemonths after radiotherapy, the lesion had healed by secondary intention (figure 4). The patient was still alive at 12 months and receiving systemic therapy.

Palliative radiotherapy for advanced breast cancer is an effective intervention that helps reduce discharge or bleeding, and reduces offensive odour associated with the condition. ${ }^{2}$ With the growing incidence and mortality of breast cancer globally, more women will stand to require palliative radiotherapy. International programmes have been developed to provide rapid access to palliative care, ${ }^{3}$ and efforts need to be streamlined in low-income

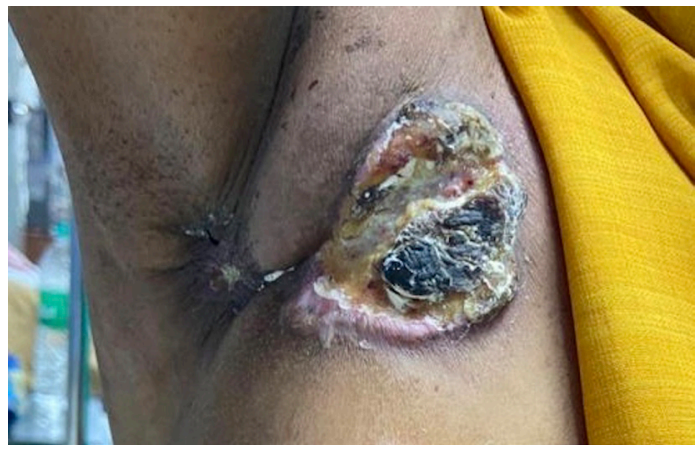

Figure 3 Good clinical response at six weeks after palliative radiotherapy. 


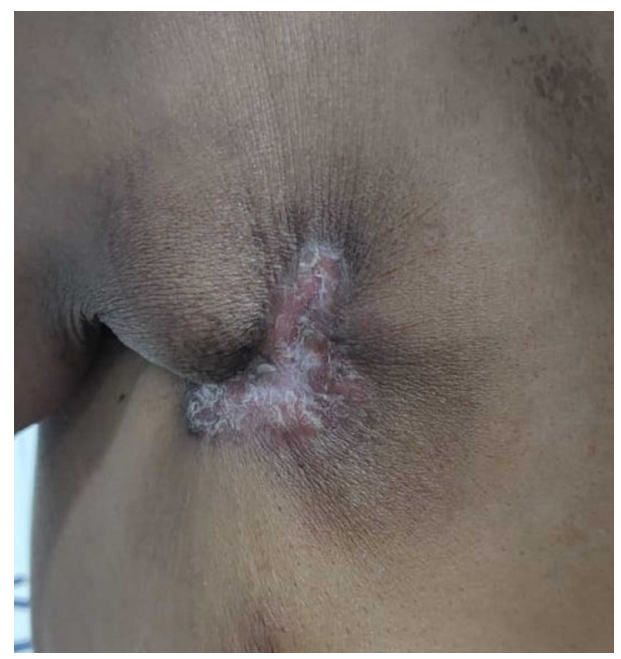

Figure 4 Clinical picture at three months after radiotherapy showing the lesion has healed by secondary intention.

and middle-income countries. ${ }^{4}$ While the use of telecobalts has declined in the Western world in the last few years, they help in resource optimisation and find utility in developing countries that often have long waitlists and a high volume of patients, and is particularly useful in palliation. For ER+/Her - MBC, while our patient received sequential therapy, the concomitant use of CDK4/6 inhibitors during radiotherapy seems safe. ${ }^{5}$

\section{Patient's perspective}

I was diagnosed with advanced breast cancer that had spread to other parts of my body, which was partially due to my neglect and seeking medical advice late. My breast ulcer had become extensive with foul odour and discharge, and I would find it difficult in social or family situations. The one-week radiotherapy schedule helped me reduce some amount of mental distress associated with my condition and helped me gain some confidence.

\section{Learning points}

- Palliative radiotherapy for advanced or ulcerated breast cancers is useful to reduce bleeding, discharge and offensive odour.

- It helps improve quality of life where cure cannot be achieved.

- Palliative radiotherapy seems safe to be combined with systemic agents.

Twitter Deep Chakrabarti @DeepOnco

Contributors DK was involved in patient management, manuscript writing and image acquisition. DC was involved in image acquisition, manuscript writing and patient management. MS was involved in patient management. MV was involved in clinical oversight and manuscript review. All authors agree to the final version of the manuscript.

Funding The authors have not declared a specific grant for this research from any funding agency in the public, commercial or not-for-profit sectors.

Competing interests None declared.

Patient consent for publication Obtained.

Provenance and peer review Not commissioned; externally peer reviewed.

\section{ORCID iDs}

Deep Chakrabarti http://orcid.org/0000-0002-9511-6844

Mranalini Verma http://orcid org/0000-0001-8446-4707

Divya Kukreja http://orcid.org/0000-0003-4961-2502

\section{REFERENCES}

1 Rembielak A, Dennis K. The evolving practice of palliative radiotherapy. Clin Oncol 2020;32:685-7.

2 Nakamura N, Kawamori J, Takahashi O, et al. Palliative radiotherapy for breast cancer patients with skin invasion: a multi-institutional prospective observational study. Jpn J Clin Oncol 2018:48:555-8.

3 Dennis $\mathrm{K}$, Harris $\mathrm{G}$, Kamel R, et al. Rapid access palliative radiotherapy programmes. Clin Oncol 2020;32:704-12.

4 Abdel-Wahab M, Fidarova E, Polo A. Global access to radiotherapy in low- and middleincome countries. Clin Oncol 2017;29:99-104.

5 Howlett S, Harvey-Jones E, Smith D, et al. Does concurrent use of Cdk4/6 inhibitors during palliative radiotherapy increase toxicity in patients with metastatic breast cancer? Clin Oncol 2021:33:e99.

Copyright 2021 BMJ Publishing Group. All rights reserved. For permission to reuse any of this content visit

https://www.bmj.com/company/products-services/rights-and-licensing/permissions/

BMJ Case Report Fellows may re-use this article for personal use and teaching without any further permission.

Become a Fellow of BMJ Case Reports today and you can:

- Submit as many cases as you like

- Enjoy fast sympathetic peer review and rapid publication of accepted articles

- Access all the published articles

Re-use any of the published material for personal use and teaching without further permission

Customer Service

If you have any further queries about your subscription, please contact our customer services team on +44 (0) 2071111105 or via email at support@bmj.com.

Visit casereports.bmj.com for more articles like this and to become a Fellow 